then return to Ballater, halting en route to view Crathie Church, then along the South Deeside Road through Pannanich and Glentanar, there being an interval for tea at some appropriate place.

Another charabanc excursion has been arranged which will take members of the Association partly along the Cairn O'Mount Road-the old main road from north to south. The starting time will be 10 a.m. from Marischal College, and from there the route lies along the south side of the Dee, thence along the valley of the Feugh to the Glen of Dye, over the Cairn O'Mount to Fettercairn and Edzell, where a halt will be made for lunch. On the return journey the route passes through Brechin and Stonehaven. Many places of historical and archæological interest are passed through on the way.

In addition to these all-day excursions, two halfday excursions have been arranged for the Saturday. The first of these leaves Marischal College at 1 p.m. by motor bus and proceeds by Castle Fraser and Monymusk, through 'Lord's Throat' to Alford, thence by Muir of Fowlis and Crossroads, Lumphanan to Tillylodge and Tarland. This excursion will return to Aberdeen about 7 p.m. The second of these excursions will leave Marischal College at 1.30 p.m. by charabanc. The itinerary is by way of Stonehaven, over the Slug Road to Banchory, on Deeside, thence to Potarch and Torphins, returning to Aberdeen at
6 p.m. This excursion is somewhat similar in interest to the preceding one.

Excursions have also been arranged by several sectional secretaries of the Association. These include visits to places of historical, archæological and geological interest, also visits to places typifying the various industries and activities of the area.

The meeting of the Association in Aberdeen has also provided an opportunity for commemorating the work of Prof. John Lamont, the Scottish astronomer and pioneer of modern terrestrial magnetism, who was born at Braemar in 1805 and was for many years director of the Royal Observatory of Munich, where he died in 1879. A sum of money has been raised to provide a monument which will be placed at Inverey near to his birthplace, and it has been arranged that the monument will be unveiled on the afternoon of Monday, September 10. A motorbus will leave Marischal College on that date at 1.30 p.m., and will convey members of the Association who desire to be present at the unveiling of the memorial, which has been fixed for 4 p.m. approximately.

The Local Committee is confident that the members of the Association will show their appreciation of the arrangements made by taking full advantage of the opportunities offered.

\title{
William Froude and Experimental Tanks
}

$\mathrm{T}$ HE summer meeting of the Institution of Naval Architects, which was held in London on June 10-13, was made the occasion of an International Conference on Experimental Tank Work. It was attended by delegates associated with experimental tanks in Great Britain and in Austria, France, Germany, Holland, Italy, Japan, Norway, Spain and the United States, and was notable for the many tributes paid to the work of William Froude (18101879) who may well be called the 'father' of the experimental tanks.

The proceedings were opened on June 10 in the hall of the Royal Society of Arts with an address by Lord Stonehaven, the president of the Institution, who said that many men of many nationalities have helped to elucidate those intriguing and often baffling problems which confront and sometimes perplex the ship designer, but there is one name which stands out above all others-that of the late William Froude, originator and pioneer of the experimental tank method of research.

Lord Stonehaven gave, in chronological order, a list of the principal tanks in the world and at the conclusion presented to the representatives of the tanks copies of Froude's portrait in bronze plaques which had been prepared for the occasion. Three papers were afterwards read, the first of these being by Sir Westeott Abell on "William Froude", while the second and third were respectively by General G. Rota of the Rome National Tank and Prof. T. B. Abell of the University of Liverpool.

Afterwards, during the proceedings, other papers were read, and there were a Government reception at Lancaster House, a dinner at Grosvenor House and various visits and excursions, including an inspection of the William Froude Laboratory at the National Physical Laboratory.

Froude's first model experiments were made in a large storage tank at the top of his house at Paignton, where he had gone to live in 1859 . He removed to a new house, "Chelston Cross", at Cockington, Torquay, in 1867. Through the suggestion of Sir Edward Reed, the Admiralty agreed to pay for the construction of a tank according to Froude's design, and thus came into existence the pioneer Torquay tank, $278 \mathrm{ft}$. long, opened in 1874 .

Nine years later, William Denny at Dumbarton built the first privately owned tank, and in 1886 the Admiralty built the naval tank at Haslar which was placed under the charge of Froude, who at his death was succeeded by his son R. E. Froude. The other tanks in Great Britain now are those of Messrs. John Brown and Co., Ltd., at Clydebank and Messrs. Vickers-Armstrong, Ltd., at St. Albans and the Yarrow tank, opened in 1911, and the new Govern. ment tank, $680 \mathrm{ft}$. long, both at Teddington. Of the last-named, opened by Mr. Baldwin in 1932, an account was given in NATURE of November 26,1932 , p. 800 .

Of the tanks in foreign countries that at Spezia was opened in 1889 , and that at Washington in 1898 . These have been followed by others at Bremenhaven 1900, Charlottenberg 1902, Paris 1905, Hamburg 1908, Nagasaki 1908, Tokyo 1910, Vienna 1919, Rome 1929, and the tank at Wageningen, Holland 1933. The Nagasaki tank was destroyed in the earthquake of 1923, while the Hamburg tank is now one of a group of five belonging to the Hamburg Model Experimental Establishment. The tanks all differ in their dimensions, and their equipment includes all the refinements rendered possible by the advance of science; but the fundamental methods employed are based on those of Froude's. Tests are carried out on models of battleships, destroyers, liners, tramps and even fishing eraft and dumb barges, and each tank is a centre of research. 